\title{
Cotton is the Mother of Poverty - Peasants, Work, and Rural Struggle in Colonial Mozambique, 1938 - 1961, by Allen Isaacman. Portsmouth, NH: Heinemann, 1996. xii, 272 pp.
}

\author{
Reviewed by Frank Hirtz, Department of Human and Community \\ Development, University of California - Davis
}

The book delivers exactly what its title and subtitle promise -- an account and the consequences of an enforced agricultural commodity regime over a time span of 23 years. It establishes impeccable standards as to how to successfully conduct interdisciplinary research of African social history. Thus, this book can serve very well as a textbook for future historians. The methodological richness employed yields stunning results. Isaacman perused archives not only in Mozambique and Portugal but also those of the cotton concessionary companies and archives in neighboring African countries. He also reviewed materials of the American Consulate in Laurenco Marques to capture the official discourse of dates, policies, and statistics alongside which the oral history can be placed.

The book gains it strength and uniqueness by interpreting this colonial period from 1938-1961 through the eyes of the subjects of this colonial policy. Anyone who has ever attempted to combine classical historical sources with interviews (in this case over 160) that Isaacman conducted with people of all walks of life in Mozambique will appreciate and admire the elegant results of such a toil. It gives the account and analysis an air of authenticity that cannot otherwise be achieved. Throughout the study, Isaacman quotes these voices with their full name as to make clear that their grievances, analyses, and judgments can stand side by side with the regularly cited classics in African history, political economy, and theories of resistance.

Not to be mistaken: this is foremost an academic book, whose major achievement is to capture the entirety of a specific agricultural colonial policy over time by turning each stone that might have repercussions on the social life of Mozambicans. Any short review cannot do justice to the wealth and breadth of material covered in this book. Almost all of the angles that Isaacman took to get to the heart of the cotton policy can very well serve as a potent lesson for the present flood of development experts advising the country's leaders on rural development policies. Refuting the 'idle labor thesis' is one case in point: for the cotton policy was, among other things, based on the assumption that there is abundant labor available and that the labor available can also much more efficiently be used for the production of a commodity for a local and international market economy. Making a living in rural (and most likely urban) Mozambique is still very hard and time consuming. Any change, enforced or induced, has to take into account the consequences of unbalancing this delicate relationship. Throughout the book Isaacman takes a perspective in which he connects most fruitfully gender issues with all aspects of rural life and economy. It not only shows how heavily women (and consequently infants and children) were affected by the introduction of cotton but also how gainfully a gendered approach can -- in the reviewer's mind must -- be employed in any sociohistorical study. In short, this book unearths the often unspeakable details of coercion, brutality, terror, racism, shortsightedness, and carelessness of the colonial Portuguese regime that made a very few rich, that impoverished the majority, and changed the entire social fabric of a society by letting people starve for a totally misguided commodity policy. By presenting these details, Isaacman disproves the often held myth of the comparatively more benevolent Portuguese colonial regime and establishes quite clearly the immense effect that colonization had on the least minutiae of 
the sociocultural environment of the subjugated people of Mozambique.

I have two major wishes and two minor points that were left unfulfilled by this book. The minor, editorial ones, first. The excellent photographs would be even more valuable if captions included a date when they were taken. Also, a glossary of Portuguese andMozambican terms, which Isaacman uses often, rightly and compellingly, can help those readers less well embedded in Mozambican society.

A more critical issue is that I do not see a major theoretical thrust around which the author's narrative and the Mozambican voices are assembled. His approach is to assert the agency, autonomy, and resourcefulness of the rural Mozambicans to eke out a living, to cope with and to forge resistance against the colonial cotton policy by documenting at the same time in admiring detail all the facets of local and international cotton policy. At the end, it leaves the reader with an encompassing description of social change: increase of rural differentiation, forms of everyday resistance, ecological change and issues of malnutrition, hunger and changes in staple foods, accounts of gross human rights violations. Further, issues that deal with the powers of the Portuguese colonizer are ever present, yet an overarching theme seems to be left unnamed. Mentioned in passing is Sen's theory of the "entitlement crisis" and considerations that deal with vulnerability. Between the lines are glimpses of the world system theory of how the peripheral colonizer Portugal incorporated Mozambique --a far away place in the periphery of the periphery-- into the global market. Yet a discussion of these major themes, i.e. entitlement crisis, vulnerability, and globalization, is conspicuously absent. I suspect, that this, and this is my second point, seems to be related to the fact that Isaacman only scantily discusses 'the colonial state' or 'the colonial administration' but presents it as if it were one unified and partly unifying force over the decades that are covered in this book. Having said that, I hasten to add that not many people would be able to address these issues all hinted at in footnotes and short asides, as adeptly as Isaacman. How to conduct such a discussion, Isaacman himself has set standards in this book that will be hard to follow. An important book, indeed.

\section{The Mekong Delta: Ecology, Economy and Revolution, 1860-1960, by Pierre Brocheux. Madison: The Center for Southeast Asian Studies, University of Wisconsin, 1995. xvii, 270 pp.}

\section{Reviewed by Joakim Öjendal, Göteborg Center for East and Southeast Asian Studies (GESEAS), Göteborg University, Sweden.}

\section{"IN THE BEGINNING THERE WAS WATER" - THE MEKONG DELTA AS A HISTORICAL SUBJECT}

The Mekong Delta is one of the areas in the world where making a living is a work of art. Marguerite Duras made her childhood experience from the delta into a literary work of art in her Un Barrage Contre le Pacifique. Albeit from 1950, that book probably has brought the Mekong Delta into more living rooms of non-Vietnamese and nonexperts than any other source. The family in her book--destitute, desperate and confused--hangs on to a piece of property that they themselves dislike and find impossible to make a good living 